\title{
History, recent development and uses of Finnsheep
}

\author{
K. MAIJALA \\ Agricultural Research Centre, Department of Animal Breeding, 31600 Jokioinen, Finland
}

\begin{abstract}
The use of Finnsheep (F) as experimental animals on fertility has created interest in the origin of it and its prolificacy. Linguistic and archeological evidence indicate that wool has been used in Finland for 2000 years and that sheep have been kept for over 1000 years. The ancestors of F may have arrived either with Finns from the present Russia, where the short-tailed and prolific Romanov breed is found, or with Vikings or western settlers from Scandinavia, where there also are short-tailed breeds. Finnish terms concerning weaving (mainly Slavic loans) speak for the former, the sheep husbandry terms (mainly Germanic loans) for the latter source.

In the 16th and 18th centuries, foreign breeds were imported to western Finland, but they were not accepted by farmers. When animals from northeastern Finland were mainly used as foundations for the herd book work, the present F may stem mainly from the original stock. The breed has long been kept in small flocks and thus been subject of inbreeding and weak selection. Since the establishment of herd book and production recording the live and fleece weights as well as litter sizes have increased. Wool was the main product until the 1920's, but meat has been most important during the last 60 years, excepting war times. Presently one aims at effective utilization of its versatility, i.e. for meat, handicraft wool, luxury furs, and forest and landscape management.
\end{abstract}

Index words: Finnsheep, prolificacy, production recording, performance changes, wool, meat, fur, multiutilization

\section{Introduction}

The increasing importance of meat in sheep production in the 1950's created interest in fertility. The low heritability estimates of fertility traits directed the attention to the great breed differences in litter size. The first prolific breed which became a subject of attention was Finnsheep $(\mathrm{F})$, which was imported by the Animal Breeding Research Organiza- tion (ABRO) to Scotland in 1962, and later on by over 40 countries in six continents. More than 3600 sheep were exported directly from Finland in 1962-86, which has helped in maintaining the breed and interest in sheep in the country.

Following the reports by DONALD and READ (1) and Maijala (6), several hundreds of articles on it have appeared (rev. 10, 7, 8), and the breed was chosen, in 1981 , to be the 
reference breed of prolific breeds in research. During the last two decades, many foreign researchers have asked, from where do $\mathrm{F}$ and its prolificacy come. Goot (2) tried to give some background information of the breed, and the present paper attempts to answer such questions.

\section{Origin and early history}

Because of the scantiness of Finnish archeological studies on animals, very little facts are available about the earlier history of $\mathrm{F}$ and also of sheep as farm animals of our ancestors. It is known, however, that wool belongs to the oldest textiles in Finnish archeology, and that it has been found from textile decorations of potteries made in the 2 nd millenium B.C. (14). The oldest peace of textile stems from ca. 300 A.D. It has been claimed by historians that sheep have been kept in Finland since the later Iron Age (ca. 1000 A.D.). In a recent study of a West-Finnish cemetery from the Viking period (800-1 000 A.D.), bone remains of either sheep or goats were found $(3,4)$.

There are two alternative main hypotheses concerning the source of F: east or west. The eastern origin is supported by the fact that most of the Finnish terms concerning weaving are Slavic loans, and that the arrival of Finns to Finland is claimed to have taken place from the area of present Soviet Union at the beginning of the first millenium A.D. It can be assumed that they had the ancestors of $\mathrm{F}$ with them and that their relatives which stayed in the north-central Russia may have had ancestors of Romanov breed which, too, is short-tailed and prolific and has some other common features with $\mathrm{F}$.

For the western origin speak the fact that most of the Finnish terms concerning sheep husbandry are Germanic loans and that shorttailed native breeds occur in all the other Scandinavian countries and in some other parts of Northern Europe. The historical time of Finland starts from the crusade of Swedish king, Eric the IX Saint, in 1154, after which Fin- land was a part of Sweden until 1809. The Vikings made excursions to our territory already in 800-1000 A.D., and newer theories consider that Finland got its inhabitants partly from the west. It is natural to assume that these people also brought farm animals with them, and hence the Swedish archeological findings (5) may be relevant also for Finland. It is generally believed that Finland has received its sheep a good thousand years ago from its southern and western neighbours, and that the breed descends from the Mouflon sheep. The question waits for reliable scientific confirmation, which may be possible with the aid of DNA techniques.

Finnish sheep husbandry long served mainly home needs of wool and furs in our cold climate, whence the animals were kept in very small self-sufficiency flocks. Meat was an important by-product. Ewes were also milked, so that in the 16th century sheep cheese was generally made. The production system may have affected selection and mating systems. Close inbreeding may have been common. It can be assumed that the biggest ram lambs, probably born as singles, were slaughtered for meat early in the autumn, while the small ones from big litters were saved for further growth and thus allowed to breed the ewes. This could be one alternative explanation to the maintenance of high prolificacy. In many other countries where sheep were economically important for the owner, rams were selected on the basis of their size, and hence mainly from single-born lambs.

\section{Recent history}

More is known about Finnish sheep husbandry from the 16th century onwards. The Swedish king Gustav Vasa who died in 1560 tried to widen and revive it by having big sheep flocks on his royal estates and by importing foreign breeds. In the middle of the 18 th century the government imported Merino sheep and tried to expand it, in order to develop our textile industry. It appointed a couple of special provincial sheepmen, who placed Merino 
rams to appropriate farms and adviced on sheep husbandry, but the farmers refused to use the rams, because they considered the wool not suitable for handweaving. Hence the impact of the importations on the native sheep remained small even in those areas where the provincial sheepmen were acting.

One reason for reluctance was a rinderpest epidemy in 1742, killing $1 / 10$ of the 400000 sheep. Since the imported breeds seemed to be more susceptible to the disease, one was not willing to acquire more of them. They were also considered more demanding concerning feeds than native sheep, which were able to utilize straws and low-quality hay harvested from unditched natural meadows.

From the middle of 19th century, the price of wool decreased decisively, affecting the economic interest in sheep production. However, sheep continued to be kept for home needs of warm clothes, wall hangings etc., for which the native breed had proved itself useful. The development of sheep numbers in Finland since 1800 A.D. is shown in Fig. 1. Great fluctuations and a great decrease after 1950 can be seen.

\section{Organization of development activities}

In the first decades of the 20th century various activities for the development of agriculture, including animal breeding, were started. The Finnish Sheep Breeders Association was established in 1918. The main objective was

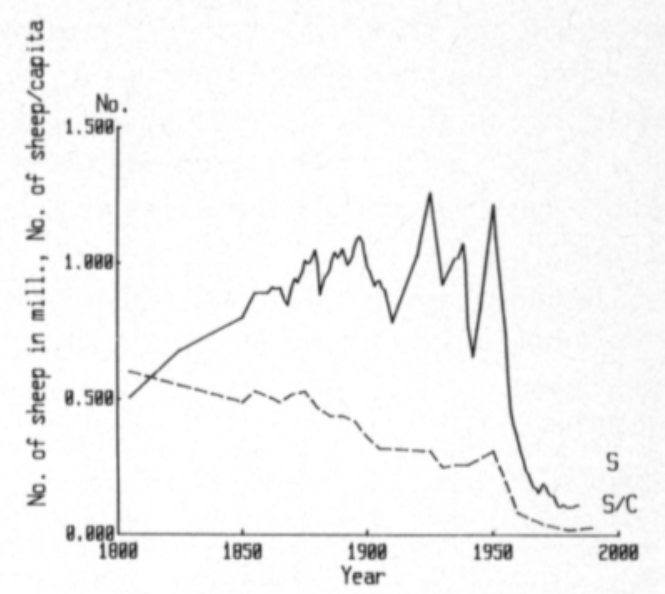

Fig. 1. Development of sheep numbers in Finland in 1805-1987. $\mathrm{S}=$ No. of sheep in mill., $\mathrm{S} / \mathrm{C}=$ No. of sheep/capita.

to improve meat production ability of the native sheep, whence prolificacy was highly appreciated. One important consequence of establishing the association and herd book was starting to record important traits and parentages. The first herd book was published in 1929, and included 113 rams and 390 ewes registered in 1922 - 29 and born in 1916-28. The average records are shown in Table 1.

At starting the herd book keeping it was realized that there was a size difference between north-eastern and south-western sheep. In the former, adult ewes weighed $40-50 \mathrm{~kg}$ and in the latter $20-40 \mathrm{~kg}$, and the corresponding weights of $7-8$ months old lambs $25-30$ and $10-18 \mathrm{~kg}$. Since the former had also been kept isolated from the imported

Table 1. Averages and ranges for various traits in the first herd book volume of Finnish Sheep Breeders' Association.

\begin{tabular}{lcccc}
\hline & \multicolumn{2}{c}{ Rams } & \multicolumn{2}{c}{ Ewes } \\
\cline { 2 - 4 } & Mean & Range & Mean & Range \\
\hline Adult live weight, kg & 63.3 & $50-83$ & 47.5 & $36-70$ \\
Fleece weight, kg/yr. & 3.29 & $2.8-4.6$ & 2.51 & $1.4-4.0$ \\
Av. litter size at birth & & & 2.19 & $1.0-5.0$ \\
Av. no. of litters & 95.4 & & 2.75 & $1-8$ \\
$\%$ white-woolled & 2.8 & & 6.2 & 6.0 \\
\% black-woolled & 1.8 & & 99.5 & \\
\% grey-woolled & 70.6 & & 0.5 & \\
\% polled & 8.3 & & & \\
\hline
\end{tabular}


breeds, it was chosen to form the basis of breeding. The reliability and reasons of the difference between areas are not known, and it is hardly possible to find representatives of both origins for studies with present-day techniques.

The annual number of animals registered in herd book has developed as follows (3-year averages:)

$\begin{array}{rcrr} & \text { Rams } & \text { Ewes } & \text { Total } \\ 1935 & 160 & 561 & 721 \\ 1945 & 191 & 1071 & 1262 \\ 1955 & 173 & 593 & 766 \\ 1965 & 98 & 658 & 756 \\ 1975 & 83 & 371 & 454 \\ 1985 & 91 & 266 & 357\end{array}$

\section{Production recording and trends}

Until 1948, production and pedigree records were obtained only from those flocks interested in registering and selling breeding animals. The most successful of such flocks were given a status of breeding centre, which were obliged to record the numbers and weights of lambs and the live and fleece weights of adults. In 1937 , for example, there were 19 breeding centres, which had a total of 289 lambing ewes and 611 lambs born.

In 1948, systematic production recording was started. Since 1981 the records have been processed with the aid of computers. The numbers of ewes and rams in the recorded flocks are shown in Fig. 2. The average number of ewes per flock has developed as follows:

\begin{tabular}{|c|c|c|c|}
\hline $1948 \quad 3.9$ & 19582.4 & $\begin{array}{lll}1968 & 12.7\end{array}$ & $\begin{array}{lll}1978 & 17.7\end{array}$ \\
\hline 19532.6 & 19633.8 & 197316.4 & 198419.9 \\
\hline
\end{tabular}

The average autumn weights of rams, ewes and lambs in Fig. 3 reveal considerable increases (from 58 to $90 \mathrm{~kg}$ in rams, from 43 to $66 \mathrm{~kg}$ in ewes, or about $50 \%$ in both sexes). It is not possible to say what is the share of genetic change in the increases.

The trends in average litter sizes are shown in Fig. 4. The means include also the values of 1-year old ewes, which have been about 0.8 lambs below those of older ewes. The aver- age number born has increased from 2.0 to 2.5 and that alive at 2 weeks from 1.85 to 2.24 . Fig. 5 shows the changes in annual weights of greasy wool. In rams the average has increased from 2.6 to $3.8 \mathrm{~kg}$ and in ewes from 2.1 to $2.9 \mathrm{~kg}$, obviously largely due to the increased size.

The figures from the systematic recording are less selected than those of registered animals in the 1920's, and still the increases in live and fleece weights as well as litter sizes are obvious.

In recent years there has been station performance testing of ram lambs, in order to find out the best rams for breeding, hopefully in AI, in spite of the small and widely dispersed flocks.

\section{Changes in uses}

There have been changes in the main uses. Wool was the main product until the end of World War I, after which the importance of meat has increased, being now $80-90 \%$ of the income. Since the sheep flocks were small and serving mainly home needs of wool, markets of sheep meat were not developed at the time there were more animals. The decrease in numbers in the 1950-60's did not stimulate slaughter houses and meat processors to develop products and markets for the urbanized human population, which thus became alienated from sheep meat. Thus, the per capita consumption of it in Finland has long been at about $300 \mathrm{~g} /$ year. Attempts to break the magic circle of low production and consumption are still topical, but it is also important to improve the marketing chains of other products of sheep, in order to utilize its versatility and improve its competitiveness.

The quality and weights of the F fleeces are not competitive as textile wool, especially when produced indoors (12), but its softness, lustre and other special qualities make it valuable material for handicraft products. The availability of black, brown and gray wool and the knowledge of the inheritance of 


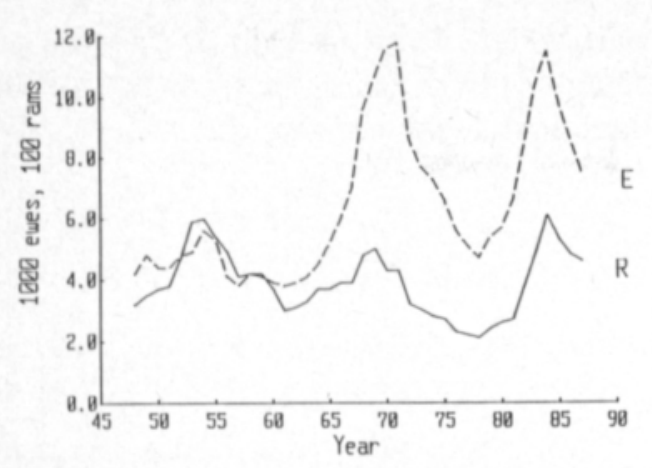

Fig. 2. Development of numbers of rams (R) and ewes (E) in Finnish recorded flocks in 1948-87.

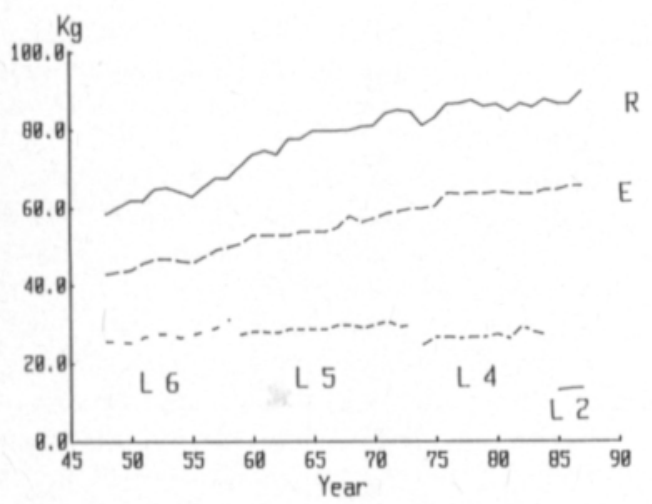

Fig. 3. Development of average live weights of rams (R), ewes (E) and lambs (L6 mo., L5 mo., L4 mo. L2 wks) in Finnish recorded flocks in 1948-87.

colours increase its value in this respect, whence this line of production, wool processing and marketing are topical aims of development activities.

Furs have been important by-products for centuries. In the 1930's a trial was made on the possibility of producing Karakul-type furs with Karakul x F crosses (13). In the 1980's, attention has been paid to the possibility of producing luxury furs from pure F. Since white is a respected colour both for its own sake and for its suitability for dyeing, Finnsheep has prospects as a fur animal. In addition, its fur is at its best at the age in which the lambs are slaughtered for meat, so that it is a real by-product. A good proportion of its furs are of suitable type, but it is being studied

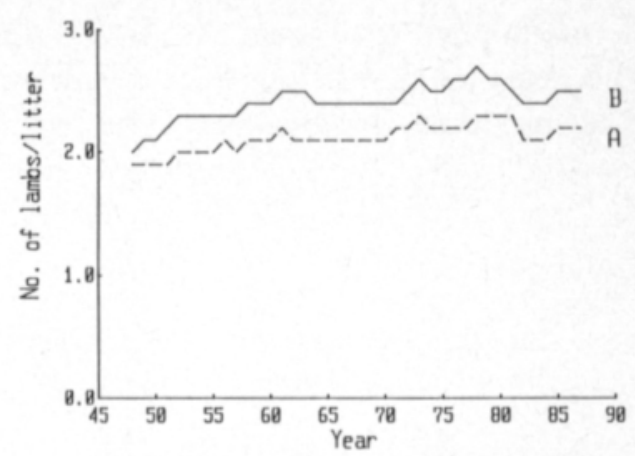

Fig. 4. Development of average litter size at birth (B) and at 2 weeks (A) in Finnish recorded flocks in $1948-87$.

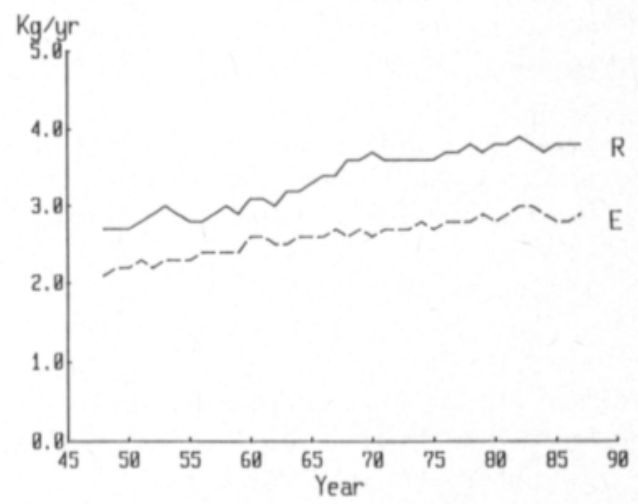

Fig. 5. Development of average greasy fleece weights of rams $(R)$ and ewes $(E)$ in Finnish recorded flocks in $1948-87$.

in more detail what type of fur is the most valuable.

The use of sheep in managing reforestation areas, established forests, landscape and lawns is increasing in importance. The use of milk for cheese making, which occurred in the 16th century, is again waking interest. Increasing milk production is important also for rearing big litters of lambs, and for this purpose one tries to develop a line with four functional teats (9).

It has been realized in the 1980's that utilization of the great versatility of sheep is important in present-day Finland, in order to maintain a sufficient sheep population for the future needs which are difficult to predict. The multiutilization has recently been discussed in 
more detail by Puntila and Maijala (11). It is necessary to utilize in each flock at least two of the products mentioned: meat, fur, wool,

\section{References}

1. Donald, H.P. \& Read, J., 1967. The performance of Finnish Landrace sheep in Britain. Anim. Prod. 9: $471-476$.

2. Goot, H., 1973. Finnsheep in Finland. Agric. Res. Org. Volcani Center, Isr. Spec. Publ. 28: 50 pp.

3. Lehtosalo-Hilander, P., 1982a. Luistari. I. The graves. Finska Fornminnesförenings Tidskrift 82: 1: $490 \mathrm{pp}$.

4. Lehtosalo-Hilander, P., 1982b. Luistari. III. A burial-ground reflecting the Finnish Viking age society. Finska Fornminnesförenings Tidskrift 82: 3: $82 \mathrm{pp}$.

5. Lepiksaar, J., 1971. Die Vorgeschichtlichen Haustiere Schwedens. In: Domestikationsforschung und Geschichte der Haustiere. Intern. Symp. (Budapest): 223-228.

6. Majuala, K., 1967. Causes of variation in litter size of Finnsheep ewes. Acta Agralia Fennica 109, 1: 136-143.

7. Maijala, K., 1980. Experiences of Finnsheep and its crosses as dams for fat lambs. Proc. Symp. Intens. Sheep Prod. (Helsinki): 2-9.

8. Maijala, K., 1984. Review of experiences about the work, milk. There are already flocks which get about $1 / 3$ of their income from each of the three first-mentioned products.

use of Finnsheep in improving fertility. Proc. 2nd World Congr. Sheep and Beef Cattle Breeding: 519-531.

9. Majula, K. \& Kyle, B., 1988. Possibilities of developing sheep which suckle from several teats. J. Agr. Sci. Finl. 60: 608-619

10. Maijala, K. \& Österberg, S., 1977. Productivity of pure Finnsheep in Finland and abroad. Livest. Prod. Sci. 4: 355-377.

11. Puntila, M.L. \& Maijala, K., 1987. Multiutilization of Finnsheep in Finland, particularly for meat, wool and furs. Abstr. 38. Ann. Meet. EAAP 2: 1048-1049.

12. Terho, T. \& Vainikainen, V., 1938. Suomalaisen lampaan villan ominaisuuksista (In Finnish). Referat: Über die Eigenschaften der Finnischen Schafwolle. Valt. Maatal.koet. Julk. 102: 56 pp.

13. VAINIKAINEN, V., 1946. Suomen karakulristeytyskokeista (In Finnish). Summary: On Karakul crossing in Finland. Valt. Maatal.koet. Julk. 128: 75 pp.

14. Vuorela, T., 1975. Suomalainen Kansankulttuuri (Finnish Peasant Culture). In Finnish. WSOY, Porvoo, $776 \mathrm{pp}$. 